\title{
Age may determine the effect of hypolipidaemic agents on plasma adipokine levels in patients with elevated low-density lipoprotein cholesterol levels
}

\author{
Zależność pomiędzy wiekiem pacjenta a wpływem leków hipolipemicznych \\ na stężenie adipokin w osoczu chorych z hipercholesterolemią \\ Robert Krysiak ${ }^{1}$, Witold Żmuda ${ }^{2}$, Bogdan Marek ${ }^{3,4}$, Bogusław Okopieńn $^{1}$ \\ ${ }^{1}$ Department of Internal Medicine and Clinical Pharmacology, Medical University of Silesia, Katowice, Poland \\ ${ }^{2}$ Invasive Cardiology, Electrotherapy and Angiology Centre, Poland \\ ${ }^{3}$ Division of Pathophysiology, Department of Pathophysiology and Endocrinology, Medical University of Silesia, Zabrze, Poland \\ ${ }^{4}$ Endocrinological Ward, Third Provincial Hospital, Rybnik, Poland
}

\begin{abstract}
Introduction: Lipid-lowering agents affect adipose tissue function. No study has investigated the role of age in the effects of hypolipidaemic agents on plasma adipokines.

Material and methods: The study was a retrospective analysis of data of 65 hypercholesterolaemic patients treated for 90 days with simvastatin, ezetimibe, or simvastatin/ezetimibe combination therapy. Circulating levels of leptin, adiponectin, visfatin, and tumour necrosis factor $\alpha$ (TNF- $\alpha$ ), as well as high-sensitivity C-reactive protein (hsCRP) were assessed separately for patients aged between 35 and 50 years and between 51 and 65 years, at the beginning and at the end of treatment.

Results: Patients in the age between 51 and 65 years had higher plasma levels of TNF- $\alpha$ and hsCRP, and lower plasma levels of adiponectin than patients aged between 35 and 50 years. In both age groups, simvastatin reduced plasma levels of hsCRP, leptin, visfatin, and TNF- $\alpha$ and increased circulating levels of adiponectin. This effect was particularly pronounced if simvastatin was administered in combination with ezetimibe. Ezetimibe alone increased plasma adiponectin and reduced plasma levels of leptin and hsCRP only in older adults. Irrespectively of age, ezetimibe administered alone did not affect visfatin and TNF- $\alpha$. The effect of simvastatin on plasma hsCRP and the investigated adipokines did not differ between both groups. In turn, the effect of ezetimibe and simvastatin/ezetimibe combination therapy on leptin, adiponectin, and hsCRP was stronger in older than in younger adults.

Conclusions: Our results show that age may partially determine the effect of ezetimibe, but not of simvastatin, on adipose tissue function. (Endokrynol Pol 2016; 67 (3): 271-276)

Key words: age; simvastatin; ezetimibe; hypercholesterolaemia; leptin; adiponectin; visfatin; tumour necrosis factor $\alpha$ (TNF- $\alpha$ )

\section{Streszczenie}

Wstęp: Leki hipolipemiczne wpływają na funkcję tkanki tłuszczowej. Jak dotąd nie przeprowadzono żadnego badania oceniającego znaczenie wieku dla działania leków hipolipemicznych na stężenie adipokin w osoczu.

Materiał i metody: Badanie stanowiło retrospektywną analizę wyników 65 pacjentów z hipercholesterolemią leczonych przez 90 dni simwastatyną, ezetimibem lub oboma tymi lekami łącznie. Stężenie w osoczu leptyny, adiponektyny, wisfatyny, czynnika martwicy nowotworów $\alpha$ (TNF- $\alpha$ ) oraz wysoko czułego białka C-reaktywnego (hsCRP) oceniano oddzielnie dla chorych w wieku od 35 do 50 lat oraz od 51 do 65 lat przed rozpoczęciem i po zakończeniu 90-dniowego protokołu badania.

Wyniki: Pacjenci w wieku 51-65 lat charakteryzowali się wyższym stężeniem w osoczu TNF- $\alpha$ i hsCRP oraz niższym stężeniem adiponektyny niż chorzy młodsi. W obu grupach wiekowych simwastatyna obniżała stężenie hsCRP, leptyny, wisfatyny, TNF- $\alpha$ oraz zwiększała stężenie adiponektyny. Wpływ na stężenie hormonów tkanki tłuszczowej i hsCRP był szczególnie wyraźnie wyrażony w przypadku łącznego stosowania simwastatyny z ezetimibem. Ezetimib zastosowany w monoterapii zwiększał stężenie adiponektyny i obniżał stężenie leptyny oraz hsCRP w grupie pacjentów pomiędzy 51. a 65. rokiem życia, ale nie w grupie chorych młodszych. Niezależnie od grupy wiekowej, nie obserwowano wpływu stosowania ezetimibu na stężeniem wisfatyny i TNF- $\alpha$. Nie obserwowano różnic w stężeniu hsCRP oraz ocenianych adipokin pomiędzy obiema grupami wiekowymi w przypadku monoterapii simwastatyną. Z kolei wplyw ezetimibu i leczenia skojarzonego na stężenie leptyny, adiponektyny i hsCRP był bardziej wyrażonych w grupie starszych niż młodszych pacjentów. Wnioski: Wyniki badania przemawiają za tym, że wpływ ezetimibu, a nie simwastatyny, na stężenie adipokin jest częściowo uwarunkowany wiekiem pacjenta. (Endokrynol Pol 2016; 67 (3): 271-276)
\end{abstract}

Słowa kluczowe: wiek; simwastatyna; ezetimib; hipercholesterolemia; leptyna; adiponektyna; wisfatyna; czynnik martwicy nowotworów $\alpha$ $(T N F-\alpha)$

This work was supported by the State Committee for Scientific Research (grant number 2 P05F 036 29).

Robert Krysiak M.D., Ph. D., Department of Internal Medicine and Clinical Pharmacology, Medical University of Silesia, Medyków 18, 40-752 Katowice, Poland, phone/fax: +48 3225239 02, e-mail: r.krysiak@interia.pl 


\section{Abbreviations}

CRP - C-reactive protein

HDL - high-density lipoprotein

HMG-CoA - 3-hydroxy-3-methylglutaryl coenzyme A

HOMA-IR - the homeostatic model assessment of insulin resistance ratio

hsCRP — high sensitivity C-reactive protein

LDL - low-density lipoprotein

NPC1L1 - Niemann-Pick C1-Like 1 transporter

TNF- $\alpha$ - tumour necrosis factor- $\alpha$

\section{Introduction}

Adipose tissue, for a long time perceived as a passive lipid storage depot, is a highly active metabolic and endocrine organ expressing and secreting a large number of mediators that affect metabolism, inflammation, and coagulation $[1,2]$. Its dysfunction, reflected by abnormal plasma levels of adipose tissue hormones (adipokines), seems to play an important role in the pathogenesis of obesity, insulin resistance, type 2 diabetes, and possibly also of cardiovascular disorders [3-7].

Aging is known to be associated with an increased risk of insulin resistance, weight, and adiposity gain [8, 9]. It is characterised by fat redistribution, decreased preadipocyte number, impaired preadipocyte function, and increased macrophage infiltration of adipose tissue, the consequence of which may be abnormal secretion of adipokines [10]. Older adults are more prone to the development of metabolic disorders, including lipid abnormalities, and cardiovascular disorders [11, 12]. These findings, suggesting the existence of adipose tissue dysfunction in the elderly, seem to be important from a clinical point of view. There are some data indicating that adipokine production and/or metabolism may determine lifespan. Centenarians, representing a healthy aging phenotype, were characterised by higher plasma adiponectin and lower plasma leptin levels than younger older and obese subjects [13]. Moreover, serum levels of total adiponectin, as well as its high molecular weight and middle molecular weight isoforms, were significantly higher in octogenarians than in corresponding middle-aged control groups [14]. Finally, dysregulation of leptin, adiponectin, and TNF- $\alpha$ was found to be a strong marker of poor prognosis in centenarians, independent of conventional risk factors [15].

3-hydroxy-3-methyl-glutaryl-CoA (HMC-CoA) reductase inhibitors (statins), being the drugs of choice for the treatment of elevated cholesterol levels and used by most patients with cardiovascular diseases, are frequently prescribed to older adults $[16,17]$. The results of our previous studies showed that adipose tissue is one of the targets for hypolipidaemic agents. Atorvastatin and fenofibric acid were found to reduce adipokine release from cultures of human adipocytes [18], as well as cultures of visceral and subcutaneous adipose tissue [19]. In turn, simvastatin, administered alone or in combination with ezetimibe, decreased plasma levels of leptin, visfatin, and TNF- $\alpha$ and increased plasma levels of adiponectin [20-22], and this effect was present in both men and women [23].

To the best of our knowledge, no previous study has investigated whether the impact of hypolipidaemic agents depends on age. Therefore, in this study we decided to compare the effects of simvastatin and ezetimibe, administered alone or in combination, on plasma adipokine levels between different age groups.

\section{Material and methods}

The study was a retrospective analysis of the previous studies of our research team [20, 22, 24]. The study protocol was approved by the local ethical committee, and all patients participating in the original studies gave their written informed consent before the beginning of the study. Patients (35-65 years old) were eligible for the study if they met the criteria of isolated hypercholesterolaemia (total plasma cholesterol more than $200 \mathrm{mg} / \mathrm{dL}$, LDL cholesterol more than $130 \mathrm{mg} / \mathrm{dL}$, and triglycerides less than $150 \mathrm{mg} / \mathrm{dL}$ ) and complied with lifestyle intervention for at least three months before the beginning of the study. We excluded patients with untreated stage 2 or 3 hypertension (according to the 2003 European Society of Hypertension-European Society of Cardiology guidelines), symptomatic congestive heart failure, diabetes, autoimmune disorders, acute and chronic inflammatory processes, thyroid diseases, chronic pancreatitis, impaired renal or hepatic function and body mass index more than $35 \mathrm{~kg} / \mathrm{m}^{2}$, as well as patients treated within three months preceding the study with drugs interfering with statins and/or ezetimibe. During the study, all patients continued to comply with the lifestyle modification (total fat intake $<30 \%$ of total energy intake, saturated fat intake $<7 \%$ of energy consumed, cholesterol intake $<200 \mathrm{mg}$ per day, an increase in fibre intake to $15 \mathrm{~g}$ per $1000 \mathrm{kcal}$, moderate to vigorous exercise for at least 30 minutes per day), as well as were treated with constant doses of simvastatin (40 mg, $\mathrm{n}=23$ ) [22], ezetimibe (10 mg, $\mathrm{n}=21$ ) [24], or simvastatin (40 mg) together with ezetimibe $(10 \mathrm{mg})(\mathrm{n}=21)$ [22] for 90 days.

Venous blood samples were taken from the antecubital vein, after a 12-hour overnight fast, in a quiet, temperature-controlled room $\left(24-25^{\circ} \mathrm{C}\right)$ between 8.00 and 9.00 a.m. (to avoid possible circadian fluctuations in the parameters studied), before and at the end of the study. Analysis was performed by a person blinded to subject 
identity and clinical details. All samples were run in duplicate and final results were averaged. Plasma lipids (total cholesterol, HDL cholesterol, LDL cholesterol, and triglycerides), glucose, and insulin were assessed by routine laboratory techniques (bioMerieux France; Incstar Corporation, Stillwater, MN, USA; Beckman, Palo Alto, CA, USA; Linco Research Inc., St Charles, MO, USA). The homeostatic model assessment of IR (HOMA-IR) was calculated as the product of glucose and insulin levels, divided by 405 . Plasma C-reactive protein levels (hsCRP) were assessed by a highly sensitive enzyme immunoassay using monoclonal antibodies (MP Biomedicals, Orangeburg, NY). Circulating levels of leptin, adiponectin, visfatin, and TNF- $\alpha$ were determined by enzyme immunoassay using reagents purchased from TECOmedical Group (Sissach, Switherland), Phoenix Pharmaceuticals (Burlingame, CA) and R\&D Systems (McKinley Place, N.E. Minneapolis, MN). The minimum detectable levels for the assessed parameters were: $0.1 \mathrm{mg} / \mathrm{L}, 7.8 \mathrm{pg} / \mathrm{mL}, 0.246 \mathrm{ng} / \mathrm{mL}, 6.1 \mathrm{pg} / \mathrm{mL}$, and $1.6 \mathrm{pg} / \mathrm{mL}$, respectively for hsCRP, leptin, adiponectin, visfatin, and TNF- $\alpha$. The intra- and interassay coefficients of variation for the assessed markers were less than 5.5 and $8.7 \%$, respectively.

The normality of distribution was determined using the Shapiro-Wilk test. Because of skewed distributions, natural logarithmic transformations were done for triglycerides, HOMA-IR, hsCRP, and adipokines. Comparisons between the groups were carried out using the $t$-test for independent samples. Student's paired $t$-test was used to determine within group differences between pre- and post-tests. $\chi^{2}$ test was used to test categorical variables. Correlations were assessed using Kendall's tau test. Differences were considered statistically significant at $\mathrm{p}<0.05$.

\section{Results}

Sex distribution, percentage of smokers, blood pressure, as well as the mean values of plasma HDL cholesterol, triglycerides, glucose, leptin, and visfatin were all comparable between both age groups (Table I). Baseline adiponectin levels were higher, while baseline TNF- $\alpha$ and hsCRP levels were lower in patients aged between 35 and 50 years than in patients aged between 51 and 65 years. The older adults had insignificantly higher levels of total cholesterol ( $p=0.068)$, LDL cholesterol $(p=0.071)$, as well as insignificantly higher values of HOMA-IR ( $\mathrm{p}=0.086$ ) and of body mass index $(\mathrm{p}=0.095)$.

Simvastatin, ezetimibe, and the combination therapy reduced total and LDL cholesterol, with no difference between the studied populations. Nor did they affect cholesterol and triglycerides. Moreover, ezetimibe
Table I. Baseline characteristics of patients

Tabela I. Wyjściowa charakterystyka pacjentów

\begin{tabular}{lcc}
\hline & $\begin{array}{c}\text { Younger } \\
\text { adults }^{*}\end{array}$ & $\begin{array}{c}\text { Older } \\
\text { adults** }^{* *}\end{array}$ \\
\hline Number of patients & 31 & 34 \\
\hline Age [years; mean (SD)] & $43(4)$ & $58(4)^{\mathrm{b}}$ \\
\hline Women (\%) & 41 & 42 \\
\hline Smokers (\%) & 26 & 24 \\
\hline Body mass index [kg/m²; mean (SD)] & $25,5(3,2)$ & $27,9(3,5)$ \\
\hline Waist circumference [cm; mean (SD)] & $95(8)$ & $98(8)$ \\
\hline Total cholesterol [mg/dL; mean (SD)] & $242(29)$ & $264(27)$ \\
\hline LDL cholesterol [mg/dL; mean (SD)] & $174(21)$ & $188(19)$ \\
\hline HDL cholesterol [mg/dL; mean (SD)] & $47(8)$ & $43(7)$ \\
\hline Triglycerides [mg/dL; mean (SD)] & $123(12)$ & $130(10)$ \\
\hline Glucose [mg/dL; mean (SD)] & $94(6)$ & $96(5)$ \\
\hline HOMA-IR [mean (SD)] & $2.5(0.7)$ & $3.1(0.8)$ \\
\hline hsCRP [mg/L; mean (SD)] & $3.1(0.7)$ & $3.9(0.8)^{\mathrm{a}}$ \\
\hline Leptin [ng/mL; mean (SD)] & $24.5(5.6)$ & $25.5(5.8)$ \\
\hline Adiponectin [mg/L; mean (SD)] & $6.2(1.4)$ & $4.7(1.1)^{\mathrm{a}}$ \\
\hline Visfatin [ng/mL; mean (SD)] & $20.8(4.0)$ & $22.1(3.4)$ \\
\hline TNF- $\alpha$ [pg/mL; mean (SD)] & $14.8(2.9)$ & $17.8(2.6)^{\mathrm{a}}$ \\
\hline
\end{tabular}

*35-50 years old; **51-65 years old; a $p<0.05$; ${ }^{\mathrm{p}} \mathrm{*}<0.001$ vs. younger adults

alone or in combination with simvastatin tended to reduce HOMA-IR (ezetimibe: younger patients $\mathrm{p}=0.068$, older patients $-\mathrm{p}=0.071$; combination therapy: younger patients $-p=0.065$, older patients $-p=0.075$ ) (Table II-IV). In both age populations, simvastatin administered alone reduced plasma levels of hsCRP, leptin, visfatin, and TNF- $\alpha$, and increased circulating levels of adiponectin (Table II). In patients between 51 and 65 years old, but not in the other age group of patients, ezetimibe reduced plasma leptin and hsCRP, but it increased circulating adiponectin. Irrespectively of age, ezetimibe did not affect visfatin and TNF- $\alpha$ (Table III). Simvastatin administered together with ezetimibe decreased plasma levels of hsCRP, leptin, visfatin, and TNF- $\alpha$, but increased plasma levels of adiponectin (Table IV). The impact of statin therapy on the investigated markers did not depend on age (Table II). In turn, the effect of ezetimibe (Table III) and simvastatin/ezetimibe combination therapy (Table IV) on hsCRP, leptin, and adiponectin, but not on the remaining variables, was more pronounced in the older than in the younger patients.

At the beginning of the study, there were positive correlations between plasma levels of leptin, visfatin, and TNF- $\alpha$ and total cholesterol, LDL cholesterol, HOMA-IR, and hsCRP (younger patients: $r$ values 
Table II. The effect of 90-day simvastatin treatment on plasma lipids, glucose metabolism markers, and circulating levels of high sensitivity C-reactive protein and the investigated adipokines in different age groups of hypercholesterolaemic patients

Tabela II. Wptyw 90-dniowego stosowania simwastatyny na stężenie lipidów, markery gospodarki węglowodanowej oraz stężenie biatka C-reaktywnego i ocenianych adipokin $w$ różnych grupach wiekowych u pacjentów $z$ izolowanq hipercholesterolemiq

\begin{tabular}{lcc}
\hline & $\begin{array}{c}\text { Younger adults* } \\
(\mathbf{n}=\mathbf{1 0 )}\end{array}$ & $\begin{array}{c}\text { Older adults* } \\
(\mathbf{n}=13)\end{array}$ \\
\hline$\Delta$ Total cholesterol [\%; mean (SD)] & $-24(8)^{\mathrm{c}}$ & $-27(6)^{\mathrm{c}}$ \\
\hline$\Delta$ LDL cholesterol [\%; mean (SD)] & $-29(7)^{\mathrm{c}}$ & $-32(7)^{\mathrm{c}}$ \\
\hline$\Delta$ HDL cholesterol [\%; mean (SD)] & $6(8)$ & $7(10)$ \\
\hline$\Delta$ Triglycerides [\%; mean (SD)] & $-14(8)$ & $-10(7)$ \\
\hline$\Delta$ Glucose [\%; mean (SD)] & $2(3)$ & $0(2)$ \\
\hline$\Delta$ HOMA-IR [\%; mean (SD)] & $5(6)$ & $5(7)$ \\
\hline$\Delta$ hsCRP [\%; mean (SD)] & $-42(10)^{\mathrm{c}}$ & $-39(8)^{\mathrm{c}}$ \\
\hline$\Delta$ Leptin [\%; mean (SD)] & $-35(11)^{\mathrm{c}}$ & $-38(10)^{\mathrm{c}}$ \\
\hline$\Delta$ Adiponectin [\%; mean (SD)] & $64(12)^{\mathrm{c}}$ & $75(18)^{\mathrm{c}}$ \\
\hline$\Delta$ Visfatin [\%; mean (SD)] & $-29(12)^{\mathrm{a}}$ & $-28(11)^{\mathrm{a}}$ \\
\hline$\Delta$ TNF- $\alpha$ [\%; mean (SD)] & $-36(11) \mathrm{c}$ & $-34(11)^{\mathrm{b}}$ \\
\hline
\end{tabular}

*35-50 years old; **51-65 years old. The data show percentage changes from the respective baseline value. ${ }^{a} p<0.05,{ }^{b} p<0.01,{ }^{c} p<0.001$ post-treatment vs. baseline value

Table III. The effect of 90-day ezetimibe treatment on plasma lipids, glucose metabolism markers, and circulating levels of high sensitivity $C$-reactive protein and the investigated adipokines in different age groups of hypercholesterolaemic patients

Tabela III. Wptyw 90-dniowego stosowania ezetimibu na stężenie lipidów, markery gospodarki węglowodanowej oraz stężenie biatka C-reaktywnego $i$ ocenianych adipokin $w$ różnych grupach wiekowych $u$ pacjentów $z$ izolowanq hipercholesterolemiq

\begin{tabular}{lcc}
\hline & $\begin{array}{c}\text { Younger adults* } \\
\text { (n = 11) }\end{array}$ & $\begin{array}{c}\text { Older adults** } \\
\text { (n = 10) }\end{array}$ \\
\hline$\Delta$ Total cholesterol [\%; mean (SD)] & $-22(6)^{\mathrm{b}}$ & $-24(7)^{\mathrm{b}}$ \\
\hline$\Delta$ LDL cholesterol [\%; mean (SD)] & $-26(7)^{\mathrm{b}}$ & $-28(7)^{\mathrm{b}}$ \\
\hline$\Delta$ HDL cholesterol [\%; mean (SD)] & $4(8)$ & $3(9)$ \\
\hline$\Delta$ Triglycerides [\%; mean (SD)] & $-8(10)$ & $-11(14)$ \\
\hline$\Delta$ Glucose [\%; mean (SD)] & $-3(2)$ & $-2(3)$ \\
\hline$\Delta$ HOMA-IR [\%; mean (SD)] & $-16(7)$ & $-18(8)$ \\
\hline$\Delta$ hsCRP [\%; mean (SD)] & $-8(12)$ & $-32(10)^{\mathrm{a}, \mathrm{c}}$ \\
\hline$\Delta$ Leptin [\%; mean (SD)] & $-8(14)$ & $-35(3)^{\mathrm{a}, \mathrm{c}}$ \\
\hline$\Delta$ Adiponectin [\%; mean (SD)] & $10(12)$ & $41(13)^{\mathrm{a}, \mathrm{c}}$ \\
\hline$\Delta$ Visfatin [\%; mean (SD)] & $-27(13)$ & $-25(11)$ \\
\hline$\Delta$ TNF- $\alpha$ [\%; mean (SD)] & $-20(14)$ & $-22(11)$ \\
\hline
\end{tabular}

*35-50 years old; "**51-65 years old. The data show percentage changes from the respective baseline value. ${ }^{a} p<0.05,{ }^{b} p<0.001$ post-treatment $v s$. baseline value; ${ }^{c} p<0.05 v s$. younger adults
Table IV. The effect of 90-day simvastatin/ezetimibe combination therapy on plasma lipids, glucose metabolism markers, and circulating levels of high sensitivity C-reactive protein and the investigated adipokines in different age groups of hypercholesterolaemic patients

Tabela IV. Wptyw 90-dniowego stosowania simwastatyny wraz z ezetimibem na stężenie lipidów, markery gospodarki węlowodanowej oraz stężenie biatka C-reaktywnego $i$ ocenianych adipokin $w$ różnych grupach wiekowych u pacjentów $z$ izolowanq hipercholesterolemiq

\begin{tabular}{lcc}
\hline & $\begin{array}{c}\text { Younger adults* } \\
(\mathbf{n}=\mathbf{1 0})\end{array}$ & $\begin{array}{c}\text { Older adults* } \\
(\mathbf{n}=\mathbf{1 1})\end{array}$ \\
\hline$\Delta$ Total cholesterol [\%; mean (SD)] & $-39(10)^{\mathrm{a}}$ & $-40(11)^{\mathrm{a}}$ \\
\hline$\Delta$ LDL cholesterol [\%; mean (SD)] & $-46(12)^{\mathrm{a}}$ & $-49(13)^{\mathrm{a}}$ \\
\hline$\Delta$ HDL cholesterol [\%; mean (SD)] & $17(9)$ & $16(8)$ \\
\hline$\Delta$ Triglycerides [\%; mean (SD)] & $-19(15)$ & $-18(14)$ \\
\hline$\Delta$ Glucose [\%; mean (SD)] & $-2(3)$ & $-3(2)$ \\
\hline$\Delta$ HOMA-IR [\%; mean (SD)] & $-18(-12)$ & $-20(-12)$ \\
\hline$\Delta$ hsCRP [\%; mean (SD)] & $-58(14)^{\mathrm{a}}$ & $-78(12)^{\mathrm{a}, \mathrm{b}}$ \\
\hline$\Delta$ Leptin [\%; mean (SD)] & $-50(19)^{\mathrm{a}}$ & $-78(11)^{\mathrm{a}, \mathrm{b}}$ \\
\hline$\Delta$ Adiponectin [\%; mean (SD)] & $82(20)^{\mathrm{a}}$ & $112(28)^{\mathrm{a}, \mathrm{b}}$ \\
\hline$\Delta$ Visfatin [\%; mean (SD)] & $-53(12)^{\mathrm{a}}$ & $-61(20)^{\mathrm{a}}$ \\
\hline$\Delta$ TNF- $\alpha[\% ;$ mean (SD)] & $-58(15)^{\mathrm{a}}$ & $-61(18)^{\mathrm{a}}$ \\
\hline
\end{tabular}

*35-50 years old; **51-65 years old. The data show percentage changes from the respective baseline value. ${ }^{\mathrm{a}} \mathrm{p}<0.001$ post-treatment $v s$. baseline value; ${ }^{b} p<0.05 v s$. younger adults

between $0.30[\mathrm{p}<0.05]$ and $0.64[\mathrm{p}<0.001]$; older patients: $r$ values between $0.34[p<0.05]$ and 0.56 $[p<0.001])$, as well as negative correlations between plasma levels of adiponectin and total cholesterol, LDL cholesterol, HOMA-IR, and hsCRP (younger patients: $r$ values between $-0.35[p<0.01]$ and $-0.60[p<0.001]$; older patients: $r$ values between $-0.37[p<0.01]$ and -0.58 [p < 0.001]). Moreover, plasma hsCRP, TNF- $\alpha$, and adiponectin, but not the remaining variables, correlated with age (hsCRP: $\mathrm{r}=0.40, \mathrm{p}<0.001$; TNF- $\alpha$ : $\mathrm{r}=0.37$, $\mathrm{p}<0.01$; adiponectin: $\mathrm{r}=-0.42, \mathrm{p}<0.001)$. In both age populations, the effect of simvastatin, ezetimibe, and combination therapy on the investigated adipokines correlated with its impact on hsCRP (younger patients: $r$ values between 0.31 [ $<<0.05]$ and $0.55[p<0.001$; older patients: $r$ values between $0.35[p<0.01]$ and 0.61 [ $p<0.001])$. Moreover, the effect of ezetimibe and simvastatin/ezetimibe combination therapy on plasma adipokines and hsCRP correlated weakly with the action on HOMA-IR (ezetimibe: younger patients $\mathrm{r}$ values between $0.30[\mathrm{p}<0.05]$ and $0.38[\mathrm{p}<0.01]$; older patients $-r$ values between $0.29[p<0.05]$ and 0.37 [ $p<0.01$ ]; combination therapy: younger patients - $r$ values between 0.28 [p < 0.05] and 0.36 [p < 0.01]; older patients $-r$ values between $0.29[p<0.05]$ and $0.35[p<0.01])$. The effect of ezetimibe and simvasta- 
tin/ezetimibe combination therapy on hsCRP, leptin and adiponectin correlated with the age of patients (ezetimibe - hsCRP: $r=0.39, p<0.01$; leptin: $r=0.37$, $\mathrm{p}<0.01$; adiponectin: $\mathrm{r}=0.39, \mathrm{p}<0.01$; combination therapy: hsCRP: $\mathrm{r}=0.37, \mathrm{p}<0.01$; leptin: $\mathrm{r}=0.32$, $\mathrm{p}<0.05$; adiponectin: $\mathrm{r}=0.35, \mathrm{p}<0.01$ ). No other correlations were found in both baseline conditions and after treatment.

\section{Discussion}

The results of this study show differences in plasma levels of adiponectin and TNF- $\alpha$, but not of other adipose tissue products, between patients belonging to both of the studied age populations. This observation is in agreement with the results of other authors [25], who observed increased plasma TNF- $\alpha$ levels and normal leptin levels in older adults. Also, in the study by Paolisso et al. [26], advancing age strongly correlated with plasma TNF- $\alpha$ concentration, and this correlation was independent of sex and body fat. A strength of our study was the strict inclusion criteria and the similar baseline characteristics of both analysed subgroups of patients. Although older and younger patients varied in body mass index, this does not seem to explain the obtained results. We think this because the difference in body mass index between both age populations was insignificant and body mass index did not correlate with plasma levels of these adipokines. Moreover, higher levels of TNF- $\alpha$ and lower levels of adiponectin were found even after adjusting for body mass index. Apart from changes in adipose tissue, the obtained results may be explained by a decrease in sex hormone levels after menopause and in men with late-onset hypogonadism. Considering the role of adiponectin and TNF- $\alpha$ in the regulation of insulin sensitivity [3, 4], age-related changes in their plasma levels may either participate in the development of insulin resistance or at least reflect impaired receptor sensitivity.

The most interesting finding of this study was the observation that ezetimibe, administered alone or in combination with a HMG-CoA reductase inhibitor, affected plasma leptin and adiponectin levels in an age-dependent manner. In the case of simvastatin/ /ezetimibe combination therapy, the obtained results cannot be attributed to the action of simvastatin because the impact of simvastatin on circulating levels of all investigated adipokines did not differ between younger and older patients. Ezetimibe is an inhibitor of Niemann-Pick C1-Like 1 transporter (NPC1L1) in the jejunal brush border, thus decreasing intestinal cholesterol absorption and reducing total and LDL-cholesterol levels [27, 28]. Although, to the best of our knowledge, no data are available in humans, aging was associated with up-regulated expression of NPC1L1 in mice [29]. However, the lack of correlation between ezetimibeinduced changes in plasma lipids and the impact of this drug on plasma hsCRP, leptin, and adiponectin suggests that non-lipid-related effects of ezetimibe are responsible for its different effect on systemic inflammation and adipose disuse in various age groups. A crosstalk between adipocytes and macrophages, being the most abundant immune cells in adipose tissue, allows the coordination of available energy stores for survival during times of starvation and pathogen challenge [30]. This cross-talk may change with age as a result of increased macrophage infiltration of adipose tissue [10]. Interestingly, monocyte-derived macrophage express NPC1L1 and other proteins bound by ezetimibe (amino peptidase $\mathrm{N}$, annexin-2, and caveolin-1) [31, 32], while ezetimibe was found to reduce the number of monocytes and the expression of monocyte chemoattractant protein-1 (MCP-1) in atherosclerotic plaques in rabbits [33]. It is possible that age-related changes in the number and function of macrophages may, at least partially, contribute to the different effect of ezetimibe in various age groups. Alternatively, the NPC1L1 inhibitor may directly affect adipocyte secretory function, and the various strengths of its action result from age-related changes in the characteristics of adipocytes.

In the whole population of patients, the effect of ezetimibe and simvastatin/ezetimibe combination therapy on plasma adipokines and hsCRP correlated with its impact on HOMA-IR, while the effect of ezetimibe was stronger in insulin-resistant than in insulin-sensitive subjects $[21,22,24]$. Correlations between adipokines or hsCRP and insulin sensitivity in ezetimibe-treated patients were also observed in both younger and older patients, analysed in the present study, but they were weak. This finding as well as only an insignificant decrease in HOMA-IR and in TNF- $\alpha$, being one of the best markers of insulin sensitivity, causatively linked with its development [3, 4], indicate that other mechanisms, not investigated in this study, may contribute to ezetimibeinduced changes in hsCRP, leptin, and adiponectin, and suggest that a favourable effect on adipokines may be observed even in non-insulin-resistant older adults.

Expectedly [34], baseline levels of hsCRP were higher in the older group of patients, and this finding may be partially explained by age-related differences in the production of TNF- $\alpha$ and adiponectin. Interestingly, the effect of ezetimibe on this protein, being a highly sensitive marker of low-grade systemic inflammation and a protein playing a direct role in the progression and instability of the atherosclerotic lesions [35], was determined by age. This observation suggests that older patients may benefit more from ezetimibe treatment than younger ones, particularly if they are at high 
cardiovascular risk. However, it should be clearly stated that even in the group of patients aged between 51 and 65 years, the effect of ezetimibe on hsCRP was more limited than that of simvastatin; therefore, ezetimibe can be considered as an alternative to statins only in individuals intolerant to statins or having contraindications to statin therapy.

We are aware of some limitations of this study. The major one is the small sample size and short treatment duration. Moreover, we only retrospectively analysed data of our previous studies. The measurement of circulating adipokine levels does not allow us to assess their action at the level of visceral and subcutaneous adipose tissues. Finally, because all patients had elevated cholesterol levels, the question whether the results would be the same if the study included patients with normal plasma lipids remains unanswered.

\section{Conclusions}

The results of the study show that the impact of ezetimibe and ezetimibe/simvastatin combination therapy partially differed between patients belonging to various age groups. This finding indicates that age differences may partially determine the effect of ezetimibe, but not of simvastatin, on adipose tissue secretory function.

\section{Acknowledgements}

This work was supported by the State Committee for Scientific Research (grant number 2 P05F 036 29). The experiments comply with the current law of Poland.

\section{References}

1. Wronkowitz N, Romacho T, Sell $\mathrm{H}$ et al. Adipose tissue dysfunction and inflammation in cardiovascular disease. Front Horm Res 2014; 43: 79-92.

2. Lanthier N, Leclercq IA. Adipose tissues as endocrine target organs. Best Pract Res Clin Gastroenterol 2014; 28: 545-558.

3. Andrade-Oliveira V, Câmara NO, Moraes-Vieira PM. Adipokines as drug targets in diabetes and underlying disturbances. J Diabetes Res 2015; 2015: 681612. doi: 10.1155/2015/681612.

4. Blüher M. Adipokines - removing road blocks to obesity and diabetes therapy. Mol Metab 2014; 3: 230-240.

5. Hajer GR, van Haeften TW, Visseren FL. Adipose tissue dysfunction in obesity, diabetes, and vascular diseases. Eur Heart J 2008; 29: 2959-2971.

6. Smith CC, Yellon DM. Adipocytokines, cardiovascular pathophysiology and myocardial protection. Pharmacol Ther 2011; 129: 206-219.

7. Bienek R, Marek B, Kajdaniuk D et al. Adiponectin, leptin, resistin and insulin blood concentrations in patients with ischaemic cerebral stroke. Endokrynol Pol 2012; 63: 338-345.

8. Han TS, Wu FC, Lean ME. Obesity and weight management in the elderly: a focus on men. Best Pract Res Clin Endocrinol Metab 2013; 27: 509-525.

9. Lechleitner M. Obesity and the metabolic syndrome in the elderly a mini-review. Gerontology 2008; 54: 253-259.
10. Zamboni M, Rossi AP, Fantin F et al. Adipose tissue, diet and aging. Mech Ageing Dev 2014; 136: 129-137.

11. Halter JB, Musi N, McFarland Horne F et al. Diabetes and cardiovascular disease in older adults: current status and future directions. Diabetes 2014; 63: 2578-2589.

12. Cigolle CT, Blaum CS, Halter JB. Diabetes and cardiovascular disease prevention in older adults. Clin Geriatr Med 2009; 25: 607-641.

13. Baranowska B, Bik W, Baranowska-Bik A et al. Neuroendocrine control of metabolic homeostasis in Polish centenarians. J Physiol Pharmacol 2006; 57 (Suppl. 6): 55-61.

14. Graessler J, Gruber M, Radke RB et al. Type 2 diabetes in octogenarians is associated with decreased low molecular weight adiponectin. Gerontology 2011; 57: 316-326.

15. Arai $\mathrm{Y}, \mathrm{Takayama} \mathrm{M}, \mathrm{Abe} \mathrm{Y}$ et al. Adipokines and aging. J Atheroscler Thromb 2011; 18: 545-550.

16. Playford DA, Watts GF. Management of lipid disorders in the elderly. Drugs Aging 1997; 10: 444-462.

17. Berthold HK, Gouni-Berthold I. Lipid-lowering drug therapy in elderly patients. Curr Pharm Des . 2011; 17: 877-893.

18. ŁabuzekK, Bułdak $€$, Duława-Bułdak A et al. Atorvastatin and fenofibric acid differentially affect the release of adipokines in the visceral and subcutaneous cultures of adipocytes that were obtained from patients with and without mixed dyslipidemia. Pharmacol Rep 2011; 63: 1124-1136.

19. Krysiak R, Łabuzek K, Okopień B. Effect of atorvastatin and fenofibric acid on adipokine release from visceral and subcutaneous adipose tissue of patients with mixed dyslipidemia and normolipidemic subjects. Pharmacol Rep 2009; 61: 1134-1145.

20. Krysiak R, Żmuda W, Okopień B. The effect of short-term simvastatin treatment on plasma adipokine levels in patients with isolated hypercholesterolemia: a preliminary report. Pharmacol Rep. 2014; 66: 880-884

21. Krysiak R, Żmuda W, Marek B et al. The effect of short-term treatment with simvastatin and ezetimibe on plasma adipokine levels in patients with isolated hypercholesterolemia. Endokrynol Pol 2014; 65: 275-280.

22. Krysiak R, Żmuda W, Okopien B. The effect of simvastatin-ezetimibe combination therapy on adipose tissue hormones and systemic inflammation in patients with isolated hypercholesterolemia. Cardiovasc Ther 2014; 32: 40-46.

23. Krysiak R, Żmuda W, Marek B, Okopień B. Comparison of the effects of short-term hypolipidaemic treatment on plasma adipokine levels in men and women with isolated hypercholesterolaemia. Endokryno Pol 2015; 66: 114-120.

24. Krysiak R, Żmuda W, Okopień B. The effect of ezetimibe on adipose tissue hormones in patients with isolated hypercholesterolemia. Pharmacol Rep 2014; 66: 442-447.

25. Bruunsgaard H, Pedersen AN, Schroll M et al. TNF-alpha, leptin, and lymphocyte function in human aging. Life Sci 2000; 67: 2721-2731.

26. Paolisso G, Rizzo MR, Mazziotti G et al. Advancing age and insulin resistance: role of plasma tumor necrosis factor-alpha. Am J Physiol 1998; 275: E294-E299.

27. Bays HE, Neff D, Tomassini JE et al. Ezetimibe: cholesterol lowering and beyond. Expert Rev Cardiovasc Ther 2008; 6: 447-470.

28. Miura S, Saku K. Ezetimibe, a selective inhibitor of the transport of cholesterol. Intern Med 2008; 47: 1165-1170.

29. Duan LP, Wang HH, Ohashi A et al. Role of intestinal sterol transporters Abcg5, Abcg8, and Npc1l1 in cholesterol absorption in mice: gender and age effects. Am J Physiol Gastrointest Liver Physiol 2006; 290: G269-G276.

30. Exley MA, Hand $\mathrm{L}, \mathrm{O}^{\prime}$ Shea $\mathrm{D}$ et al. Interplay between the immune system and adipose tissue in obesity. J Endocrinol 2014; 223: R41-R48.

31. Seedorf U, Engel T, Lueken A et al. Cholesterol absorption inhibitor ezetimibe blocks uptake of oxidized LDL in human macrophages. Biochem Biophys Res Commun 2004; 320: 1337-1341.

32. Orsó $E$, Werner $T$, Wolf $Z$ et al. Ezetimib influences the expression of raft-associated antigens in human monocytes. Cytometry A 2006; 69: 206-208

33. Gómez-Garre D, Muñoz-Pacheco P, González-Rubio ML et al. Ezetimibe reduces plaque inflammation in a rabbit model of atherosclerosis and inhibits monocyte migration in addition to its lipid-lowering effect. $\mathrm{Br}$ J Pharmacol 2009; 156: 1218-1227.

34. Singh T, Newman AB. Inflammatory markers in population studies of aging. Ageing Res Rev 2011; 10: 319-329.

35. Ridker PM. Inflammatory biomarkers and risks of myocardial infarction, stroke, diabetes, and total mortality: implications for longevity. Nutr Rev 2007; 65: S253-S259. 